\title{
INOVASI LAYANAN BIMBINGAN DAN KONSELING DI PADA PEMBELAJARAN DALAM JARINGAN MASA PANDEMI COVID-19
}

\author{
M Adi Putra AP \\ SMK Negeri 2 Lamongan/e-mail: adiputra.smkn2@gmail.com \\ Nurida Shofaria \\ SMK Negeri Sarirejo/e-mail: nuridashofaria01@gmail.com
}

\begin{abstract}
Abstrak
Dalam masa pandemi covid-19 sesuai dengan keputusan menteri pendidikan tentang WFH (Work From Home) dan SFH (Study From Home) atau pembelajaran dalam jaringan. Sekolah tidak lagi tempat bertemunya peserta didik dan guru melainkan semua pembelajaran dilakukan melalui daring. Tidak ada alasan apapun dalam masa pandemi covid-19 guru bimbingan konseling/konselor berhenti memberikan layanan kepada peserta didik, bahkan dengan adanya pandemi seperti ini semua guru bimbingan konseling dikenalkan dengan beberapa macam metode aplikasi pembelajaran daring, di tuntut melakukan inovasi-inovasi layanan kepada peserta didik sehingga menambah keterampilan diri dalam menggunakan layanan bimbingan konseling berbasis daring, mengoptimalkan layanan konseling, serta meningkatkan peran serta teman dalam konseling sebaya. Sehingga layanan bimbingan dan konseling di masa pandemi covid-19 masih bisa berjalan efektif. Kata kunci: innovasi layanan bimbingan dan konseling, pandemic covid-19
\end{abstract}

\begin{abstract}
During the Covid-19 pandemic the latest education model, namely students experiencing Study From Home (SFH) and counseling teachers implementing Work From Home (WFH) Schools are no longer a meeting place for students and teachers but all learning is done online. There is no reason whatsoever during the Covid-19 pandemic, counseling guidance teachers / counselors stop providing services to students, even with a pandemic like this, all counseling guidance teachers are introduced to several kinds of online learning application methods, demanded to make service innovations to participants students so as to increase their personal skills in using online-based counseling guidance services, optimize counseling techniques, and increase the participation of friends in peer counseling. So that guidance and counseling services during the Covid-19 pandemic can still run effectively.
\end{abstract}

Keywords: Covid-19 pandemic, counseling guidance innovation

\section{PENDAHULUAN}

Akhir Februari 2020 Indonesia mengalami perubahan yang luar biasa berawal dari masuknya Covid-19 (Corona virus Diseases 19) di negeri ini membawa dampak yang luar biasa pula, bahkan berpengaruh besar pada model pendidikan di negeri ini. Dalam keadaan pandemi Covid-19 ini, layanan pendidikan harus tetap berlangsung. Hal ini dikarenakan tidak saja terkait dengan masa depan peserta didik yang notabene generasi penerus bangsa, tetapi juga keberlangsungan sistem layanan pendidikan kepada masyarakat di negeri ini.

Sejak Menteri Pendidikan dan Kebdayaan Nadiem Makarim menerbitkan surat edaran tentang Study from Home (SFH) pada Maret 2020, hampir tujuh bulan peserta didik belajar dari rumah yang bertujuan untuk menghindari Covid-19. Pandemi covid-19 tidak hanya mengakibatkan peserta didik belajar dari rumah, guru pun di tuntut untuk lebih kreatif bekerja, mengajar, memberikan layanan dari rumah juga, tidak menutup kemungkinan guru bimbingan dan konseling yang mana sebelum pandemi covid-19 memberikan layanan ke peserta didik dengan mudah, bertatap muka di ruang konseling komunikasi langsung dan mudah membaca gerak tubuh peserta didik, kini saatnya guru bimbingan konseling dituntut berinovasi lebih aktif dan kreatif dalam memberikan layanannya ke peserta didik tentunya melalui lananan online, pembelajaran daring dan konseling daring.

Dalam masa pandemi covid-19 model pendidikan yang terbaru yakni peserta didik mengalami Study From Home (SFH) dan guru 
Bimbingan konseling melaksanakan Work From Home (WFH) Sekolah tidak lagi tempat bertemunya peserta didik dan guru melainkan semua pembelajaran dilakukan melalui daring.

Saat ini, kecanggihan teknologi informasi telah merubah segalanya menjadi nyata. Hal ini terbukti dari adanya pembelajaran jarak jauh yang membutuhkan sarana informasi cepat, efisien, dan tidak terbatas akan ruang serta waktu. Sehingga kemajuan suatu bangsa di era informasi saat ini bergantung pada kemampuan IT masyarakat dalam memanfaatkan pengetahuan untuk meningkatkan kualitas kehidupan. Lebih-lebih pemanfaatan dunia digital pada dunia pendidikan. Hal tersebut dikenal dengan istilah Knowledge Based Society atau Masyarakat Berbasis Pengetahuan.

Semua tenaga pendidik dan peserta didik wajib belajar melalui beberapa model pembelajaran daring, tentunya banyak pilihan aplikasi yang bisa digunakan sebagai penunjang pemberian layanan bimbingan konseling daring. Guru bimbingan konseling pun berlomba-lomba berinovasi dan belajar hal-hal baru, berusaha mampu mengaplikasikan pembelajaran daring.sebab siapa yang menguasai kecanggihan teknologi informasi maka ia akan siap dan mampu bersaing dalam masa pandemi Covid-19 saat ini. Sehingga semua negara terdampak Covid-19 berlomba untuk mengaplikasikan dan mengintegrasikan media internet disetiap aktivitas masyarakatnya.

Selanjutnya dengan perkembangan masa pandemi Covid-19 saat ini masalah muncul dan tantangan baru lebih berat bagi peserta didik maupun guru bimbingan dan konseling. Jauh sebelum terjadi pandemi Covid-19 muncul, Robert B Tucker (2002) telah mengidentifikasi sepuluh tantangan abad 21. Dan tentangan tersebut masih sesuai di masa pandemic Covid-19 saat ini. (1) kenyamanan (convinienc), (2) kecepatan (speed), (3) gelombang generasi (age wave), (4) pilihan (choice), (5) ragam gaya hidup (life style), (6) kompetisi harga (discounting), (7) pertambahan nilai (value added), (8) pelayananan pelanggan (costumer service), (9) teknologi sebagai andalan (techno age), dan (10) jaminan mutu (quality control).

Sepuluh tantangan di atas menuntut inovasi baru yang mampu menyesuaikan dengan paradigma baru dalam pendidikan. Dalam hal ini sesuai dengan kondisi pendidikan era pandemic Covid-19, yaitu. (1) accelerated learning, (2) learning revolution, (3) megabrain, (4) quantum learning, (5) value clarification, (6) learning than teaching, (7) transformation of knowledge, (8) quantum quotation (IQ, EQ, SQ, dll.), (9) process approach, (10) Forfolio evaluation, (11) school/community based management, (12) school based quality improvement, (13) life skills, serta (14) competency based curriculum.

Bimbingan dan Konseling adalah suatu proses pemberian bantuan pada peserta didik terlebih pada peserta didik yang tidak melaksanakan pembelajaran tatap muka. Sehingga dapat dilaksanakan melalui berbagai metode layanan bimbingan dan konseling. Layanan bimbingan konseling saat ini semakin berkembang. Tidak hanya dilakukan melalui tatap muka, namun juga dapat memanfaatkan media Handphone (Android) atau teknologi informasi lain yang dimiliki. Seperti, aplikasi whatsapp, google classroom, zoom, google, dsb. Hal tersebut bertujuan untuk menjadikan layanan bimbingan dan konseling lebih dekat, komunikatif interaktif, dan inovatif terutama dalam pembelajaran daring dengan peserta didik saat pandemi Covid-19. Namun, tetap mengedepankan dan memerhatikan azas-azas dalam kode etik bimbingan dan konseling.

\section{Inovasi layanan bimbingan dan konseling masa pandemi Covid-19}

Inovasi merupakan upaya memunculkan dan mewujudkan ide serta gagasan sebagai suatu proses dari hasil pengembangan pemanfaatan maupun mobilisasi pengetahuan, keterampilan, serta pengalaman dalam menciptakan atau memperbaiki suatu produk, proses, dan/atau sistem yang dianggap baru. Dalam hal ini bertujuan agar mampu memberikan nilai yang berarti atau signifikan.

Dalam Undang-Undang Nomor 19 Tahun 2002 tentang pengertian inovasi, disebutkan bahwa inovasi merupakan " kegiatan penelitian, pengembangan, dan atau pun perekayasaan yang dilakukan dengan tujuan melakukan pengembangan penerapan praktis nilai dan konteks ilmu pengetahuan yang baru, atau pun cara baru untuk menerapkan ilmu pengetahuan dan teknologi yang sudah ada ke dalam produk atau pun proses pembelajarannya".

Begitu halnya dalam bidang bimbingan dan konseling, inovasi merupakan usaha untuk mewujudkan suatu gagasan/ide, metode, cara, atau sarana alat yang diciptakan oleh konselor/guru BK yang sebelumnya telah diamati terlebih dahulu sebagai suatu hal yang benar-benar baru dan diharapkan mampu digunakan dalam mencapai suatu tujuan tertentu serta menjadi solusi dari suatu pemecahan masalah dalam bidang bimbingan dan konseling.

Fullan \& Stiegelbauer (1991) mengemukakan bahwa terdapat tiga elemen intrinsic yang harus dimiliki dalam setiap inovasi.

(1) Bentuk (form). Hal ini berkaitan dengan bentuk fisik yang dapat diamati secara langsung dan membutuhkan tatap muka substansi yang terkandung dari sebuah inovasi dahulu sebelum pandemi covid-19 guru bimbingan konseling selalu memberikan form ke peserta didik dalam bentuk paper, namun saat ini dalam masa pandemi covid-19 form yang di bagikan guru bimbingan konseling ke peserta didik dalam bentuk file/aplikasi atau daring. Misalnya, seorang guru bimbingan konseling ingin 
mengetahui data pribadi siswa guru bimbingan konseling tinggal membuat melalui google form dan dibagikan di group Whatsaap siswa, lebih mudah dan praktis dalam penanganannya dan hal itu dapat juga digunakan sebagai bentuk lain dari pendekatan bimbingan dan konseling komprehensif yang dapat dipahami sebagai layanan bimbingan dan konseling. Hal ini terintegrasi dengan proses pendidikan di sekolah melalui komponen program yang dirancang secara menyeluruh dan saling berkaitan dengan layanan dasar bimbingan, layanan responsif, perencanaan individual, serta dukungan sistem.

(2) Fungsi (function). Memiliki makna kontribusi atau manfaat yang dihasilkan dari inovasi terhadap kehidupan anggota dalam suatu sistem pendidikan. Dicontohkan pada fungsi pendekatan daring yang diperoleh dapat saja mengacu pada pendekatan bimbingan dan konseling komprehensif yang memfasilitasi pencapaian tugas-tugas perkembangan konseli sehingga mampu memandirikan siswa.

(3) Makna (meaning). Intensitas manfaat yang diberikan melalui inovasi guna pengguna inovasi itu sendiri yakni guru bimbingan konseling agar mudah dalam bekerja dan tetap memberikan layanan ke peserta didik walaupun dalam masa pandemi Covid19. Misalnya, bahwa melalui layanan pendidikan daring tujuan untuk memandirikan peserta didik dapat tercapai serta dpat membantu mengentaskan permasalahan pembelajarn siswa dengan layanan konseling daring.

Berdasarkan uraian di atas, layanan informasi Bimbingan Konseling berbasis daring merupakan bagian dari sistem sekolah yang mampu membantu siswa dalam mengatasi persoalan yang dihadapi saat proses belajar-mengajar agar mencapai perkembangan peserta didik yang maksimal. Dalam hal ini, segala usaha dapat dilakukan guna menjalin hubungan kedekatan emosi antara guru bimbingan konseling dengan peserta didik. Usaha ini pun dilakukan guna mengaplikasikan program layanan bimbingan konseling yang telah terkonsep sebagai empat komponen layanan bidang bimbingan dan konseling. Empat komponen layanan bidang tersebut yaitu bimbingan pribadi, sosial, belajar, dan karier. Tujuan dari bimbingan pribadi adalah agar konseli/peserta didik bisa membuat dan memonitor konsep diri yang menyenangkan, mampu memahami kelemahan dan kelebihan yang dimiliki serta bisa menerima kondisi yang terjadi saat ini. Pada masa pandemic Covid-19 ini, melalui bimbingan pribadi, diharapkan siswa mampu

1. Mempersiapkan diri untuk baeradaptasi dengan lingkungan sekitar, selalu menjaga diri, mengutamakan kesehatan dan mampu dengan gaya hidup sehat.

2. Mampu Menganalisis potensi diri, kekuatan dan kelemahan pada dirinya.
3. Mengukur tingkat pencapaian tujuan dirinya.

4. Mengambil keputusan yang merefleksikan perencanaan dirinya.

5. Memahami dan berani mengambil keputusan untuk dirinya.

Layanan bidang bimbingan sosial merupakan suatu layanan yang membantu peserta didik dalam memahami dan menilai serta mengembangkan kemampuan interaksi sosial yang sehat dan efektif dengan teman sebaya, anggota keluarga, serta masyarakat sekitar terutama dalam masa pandemi covid-19. Di masa pandemi covid-19 saat ini melalui bimbingan sosial, diharapkan peserta didik dapat:

1. Memahami batasan/ jaga jarak ketika berkomunikasi dengan orang lain,

2. Selalu menjaga hubungan harmonis dengan keluarga, teman serta masyarakat sekitar

3. Mampu menjaga interaksi dengan masyarakt sekitar dengan petunjuk protokol kesehatan

Bimbingan pengembangan kemam-puan belajar adalah bidang pelayanan yang membatu peserta didik mengembangkan kemampuan belajar secara optimal dalam masa pandemic covid-19 dalam hal ini pembelajaran mandiri maupun daring. Di masa pandemi covid-19 saat ini melalui bimbingan belajar, diharapkan peserta didik dapat:

1. Menerapkan belajar mandiri efektif

2. Mampu beradaptasi dengan pembelajaran daring

3. Mampu mengoptimalkan waktu kesehariannya dengan belajar

Bimbingan karier adalah bidang pelayanan yang membantu peserta didik dalam memahami dan menilai informasi, serta memilih dan mengambil keputusan karier, dalam hal ini termasuk perencanaan studi lanjut. Di masa pandemic covid19 sat ini melalui bimbingan karier, di harapkan pesert didik dapat:

1. Membuat peta konsep perencanaan studi lanjut/rencana karier setelah lulus sekolah

2. Mampu melihat peluang usaha/kerja dalam situasi sulit pandemic covid-19

3. Mampu berwirausaha dalam dan setelah masa pandemic covid-19

Tujuan dari empat bidang layanan di atas lebih bersifat informatif, sangat cocok dengan metode pembelajaran daring sehingga guru bimbingan konseling perlu membangun sebuah layanan informasi berkelanjutan dalam masa pandemi maupun pasca pandemi tentunya guru bimbingan konseling dituntut untuk selalu berfikir dinamis dan obyektif dengan konten yang menarik 
serta mudah di pahami peserta didik, yakni memberikan kemudahan siswa mendapatkan layanan bimbingan konseling melalui daring.

\section{Konseling daring}

Konseling daring atau konseling lewat dunia maya merupakan bukan hal baru, jika sebelumnya konseling daring menggunakan Email atau lewat inbox Facebook. Dalam pandemi covid19 saat ini perkembangan mode daring sangat pesat, konseling lebih mudah dengan whatsapp, semakin canggih, dan mudah dalam pengoperasiannya sehingga menuntut guru bimbingan dan konseling agar lebih aktif dan proaktif dalam mengikutinya. Sehingga tidak tertinggal dalam memberikan layanan bimbingan dan konseling sesuai dengan era pandemic Covid-19 saat ini. Salah satu tindakan pengembangan atau inovasi yang dapat dilakukan oleh konselor yaitu melalui pemberian layanan konseling melalui aplikasi Video Call Whatsapp. Konseling dengan metode ini sangat efektif terutama pada saat era pandemi covid-19 ini dan bagi guru bimbingan konseling yang tidak memiliki jam tatap muka dalam struktur kurikulum sekolah yang tidak terjadwal pada setiap minggunya.

Konseling yang dilakukan melalui Video Call Whatsapp tidak sulit/rumit dilakukan. Hal tersebut dikarenakan hampir semua guru bimbingan konseling dan peserta didik memiliki HP Android, telah terbiasa dalam mengaplikasikan teknologi informasi Whatsapp (WA), serta hampir semua sekolah telah memiliki akses wifi. Guru bimbingan konseling hanya tinggal mengomunikasikan program BK yang telah dikonsep melalui kegiatan layanan konseling daring kepada pihak terkait di sekolah, dalam hal ini ranah wakasek kurikulum agar dapat terlaksana dengan lancar. Hal ini sangatlah penting dikarena merupakan salah satu kewajiban sekolah dalam memfasilitasi program yang dimaksud dukungan sistem.

\section{Sinema Konseling moda daring}

Sinema konseling merupakan bentuk konseling kreatif, yang mana seorang konselor mampu menampilkan film pendek atau video sebagai metode konseling. Bahkan saat ini Youtube merupakan salah satu sarana pembelajaran daring. Konselor bisa membuat konten Youtube sendiri maupun dari link Youtube yang tersedia dalam menyusun materi pembelajaran. Solomon (2011) berpendapat bahwa berpensinema konseling merupakan suatu metode yang mengunakan film dalam sebuah proses konseling sehingga berdampak positif pada konseli, terkecuali pada konseli gangguan psikotik. Solomon dalam Anindito (2008) juga menyebutkan bahwa masalah yang mudah dikonseling melalui sinema konseling diharapkan mampu menumbuhkan motivasi, memperbaiki hubungan, serta penanganan pada depresi.
Menurut Demir (2007) sinema konseling biasanya menggunakan subyek tidak terlalu banyak agar lebih focus hanya terdiri atas empat hingga delapan konseli dan berlangsung lebih kurang hingga 90 menit serta didokumentasikan menggunakan variabel yang terukur. Selain itu, dijelaskan pula oleh Demir (2007) bahwa sinema konseling merupakan pengembangan dari bibliokonseling yang merupakan suatu layanan konseling dengan menggunakan sumber bacaan (buku) dalam membantu kliennya. Menurut Ulus dalam Demir (2007), sinema konseling lebih efisien dan menarik daripada bibliokonseling. Melalui youtube sinema konseling lebih mudah diakses daripada bibliokonseling. Hal ini dikarenakan menonton film lebih mudah dan lebih asyik, serta dilengkapi animasi gambar/suara daripada membaca buku. Melalui menonton film, waktu lebih efisien dan praktis dibandingkan membaca buku. Oleh sebab itu, peserta didik dapat mengakses youtube dimanapun berada melalui handphone.

Ditinjau dari hasil dan proses konseling, film lebih efektif dan efisien dibandingkan menggunakan metode membaca buku. Peserta didik saat ini cenderung lebih tertarik dan mudah mengamati ketika mereka melihat film daripada membaca buku. Woltz (2004) mengungkapkan bahwa sinema konseling merupakan konseling yang lebih spesifik, dalam hal ini konselor bukan hanya menampilkan sebuah film, namun juga memilih kesesuaian porsi film sesuai dengan tujuan konseling yang ingin dicapai.

Begitu halnya menurut Gregerson (2010), Cinematherapy merupakan intervensi terapeutik yang memungkinkan klien menilai secara visual karakter-karakter yang ada dalam film yang berinteraksi dengan orang lain, lingkungannya, dan masalah-masalah pribadinya. Melalui film, seorang konselor dapat membantu memperkuat aliansi terapeutik dengan komunikasi dan pengalaman antara klien dan terapis.

Nola Kortner dalam Eliasa \& Iswanti (2014) menyebutkan bahwa cinema-therapy yang merupakan bagian dari biblio-therapy mampu untuk membantu klien dalam meningkatkan ketahanan emosi dan tekanan mental, pembentukan selfconcept dan self-accepted.

Berdasarkan uraian di atas, dapat disimpulkan bawah sinema konseling merupakan sebuah metode layanan konseling kepada peserta didik yang menggunakan film atau video pendek yang dapat dilakukan secara individu ataupun berkelompok serta memiliki tujuan tertentu yang menghasilkan efek positif. Hal tersebut dikarenakan pada masa pandemi Covid-19 saat ini, peserta didik lebih mudah dalam melihat konten youtube yang telah disediakan konselor/guru bimbingan konseling yang berkaitan dengan pengambangan pribadi, sosial, belajar, serta karier. 
Prosedural dalam pelaksanaan sinema konseling dari Youtube, diantaranya a) mempersiapkan konten film; b) refleksi isi film; c) refleksi diri; d) pembentukan komitmen; e) uji komitmen; serta f) refleksi pengalaman. Film atau video dari Youtube yang digunakan dalam sinema konseling memiliki durasi bervariasi paling lama 60 menit, namun lebih efektif 20 hingga 30 menit sehingga peserta didik tidak jenuh saat melihat layar handphone. Selain itu, melalui adanya proses editing, diharapkan konselor mampu melakukan pemilihan bagian mana yang dianggap layak atau tidak jika ditonton peserta didik dan mengetahui seberapa jauh efek setelah penayangan film tersebut. Sebelum menampilkan sinema konseling hendaknya konselor/guru bimbingan konseling memahami alur cerita film atau video sehingga mampu menampilkan konten yang cocok atau disukai oleh peserta didik serta mampu memilih tokoh yang sesuai kebutuhan dan cocok dengan usia perkembangan peserta didik. Hal ini diharapkan guna lebih memermudah daya tangkap peserta didik terhadap pesan yang hendak disampaikan melalui film tersebut. Hendaknya guru bimbngan konseling menyusun konsep kegiatan yang telah disampaikan di atas, sebab hal ini berpengaruh terhadap kesuksesan dari konseling itu sendiri. Serta konsep yang sistematis akan mendukung kesuksesan pelaksanaan sinema konseling via Youtube.

\section{Kefektifan Sinema Konseling di Masa Pandemi Covid-19}

Dalam sinema konseling mencakup banyak konten, bisa menggunakan konten motivasi dengan cara gelak tawa, perjuangan hidup serta pengalaman-pengalaman orang sukses dan terdapat beberapa manfaat antara lain:

1. Tertawa merupakan bagian dari terapi. Sebuah penelitian ilmiah telah membuktikan bahwa tertawa mampu meningkatan sistem kekebalan imun. Pada saat pandemi Covid-19 ini, kekebalan imun adalah kunci keamanan tubuh dari serangan virus. Tertawa juga sangat efektif dalam mengurai hormon stres yang menyebabkan penyempitan pembuluh darah serta menekan aktivitas hormon (epinefrin dan dopamin). Dalam keadaan penuh masalah dan tekanan, film/video lucu dapat menjadi sarana ampuh untuk meningkatkan mood.

2. Menangis merupakan salah satu bentuk katarsis emosional. Dalam sebuah tontonan yang membuat seseorang ikut menangis mampu merangsang pelepasan emosional yang terpendam, selanjutnya akan menciptakan suasana plong, perasaan lega, dan mampu menumbuhkan semangat baru untuk membuka pemikiran/ide baru.

3. Menumbuhkan harapan baru, tidak ada tontonan yang dengan sendirinya dapat membalikkan pandangan dunia yang negatif. Lain halnya dengan seseorang yang merasa putus asa, tontonan yang dimulai dengan cerita mengenai keputusasaan dan berakhir pada kebahagiaan mampu memberikan suasana baru. Tontonan tersebut akan membawa orang tersebut seolaholah berada dalam cerita tersebut dan merasakan seperti pada cerita sehingga mampu memunculkan sikap optimis serta suasana baru dalam pemikirannya

4. Mempertanyakan konsep pemikiran negatif terhadap diri serta menemukan kembali konsep pemikiran positif. Seseorang mungkin miliki pemikiran negatif tentang dirinya, tidak menyadari kekuatan yang dimiliknya, dan tidak mengetahui cara mengoptimalkan potensi dirinya. Melalui refleksi cerita dan karakter yang telah ia tonton, sesesorang tersebut mampu menemukan kekuatan yang sebenarnya ada dalam diri, integrasi kehidupan tidak nyata kedalam kehidupan nyata bisa saja terjadi ketika seseorang bercermin pada yang mereka tonton.

5. Memperbaiki hubungan komunikasi yang kurang baik dapat dilakukan pula melalui tontonan film/video. Melalui menonton video/film bersama-sama dan menjelaskan kepada teman mengenai alasan memilih tontonan tersebut, maka dimungkinkan mampu terjalin tegur sapa yang lebih terarah. Tontonan film/video mampu berfungsi sebagai metafora yang mungkin bisa untuk mewakili perasaan maupun pemikiran serta ide-ide dari pada katakata dari seseorang yang kesulitan dalam penyampaiannya.(Ni’ma,2018)

\section{Keefektifan peran Konselor Sebaya di masa pandemic covid-19 \\ "Peer counseling is the use problem} solving skills and active listening, to support people who are our peers" (Kan, 1996). Konseling sebaya adalah penggunaan keterampilan pemecahan masalah dan mendengarkan secara aktif, untuk mendukung orang-orang yang membutuhkan solusi dari masalahnya. Meskipun demikian, Kan mengakui bahwa keberadaan konseling teman sebaya merupakan kombinasi dari dua aspek yaitu teknik dan pendekatan yakni konseling teman sebaya dengan dukungan sebaya (peer support). Menurut Kan peer support lebih bersifat umum (bantuan informal; saran umum dan nasehat yang diberikan oleh dan untuk teman sebaya); sementara peer counseling merupakan suatu metode yang terstruktur. Konseling sebaya merupakan suatu bentuk pelatihan psikologis yang disengaja dan sistematis. Konseling sebaya memungkinkan peserta didik untuk memiliki keterampilan untuk mengimbaskan kepada teman yang lain yang memberikan pengalaman kemandirian dan kemampuan mengontrol emosi yang sangat bermakna sesama peserta didik. 
Derdasarkan uraian di atas, didefinisikan bahwa konseling sebaya merupakan layanan bantuan konseling yang diberikan oleh teman sebayanya (biasanya seusia/teman satu jurusan/satu kelas) yang terlebih dahulu diberikan pelatihanpelatihan untuk menjadi konselor sebaya. Sehingga diharapkan mampu memberikan bantuan baik secara individu maupun kelompok kepada temantemannya yang bermasalah ataupun mengalami berbagai hambatan dalam perkembangan kepribadiannya.

Dalam pandemi covid-19 saat ini keberadaan teman adalah hal yang utama dalam mengurangi kebosanan ketika lama berada dalam rumah. Ketika terbiasa bergaul bebas, pulang sekolah bermain, nongkrong dsb. Namun saat pandemic covid-19 saat ini membatasi gerak bermain peserta didik, shingga keberadaan teman merupakan hal yang penting walaupun komunikasi via daring. "Mereka yang menjadi konselor sebaya bukanlah seorang yang profesional di bidang konseling, namun mereka diharapkan mampu menjadi perpanjangan tangan konselor professional" (Erhamwilda, 2009).

Melalui layanan peer counseling di era pandemic Covid-19 ini, sekolah menyiapkan peserta didiknya tertentu untuk menjadi konselor nonprofesional dalam membantu menyelesaikan masalah teman-temannya. Menjadi teman curhat, menjadi teman diskusi masalah temannya merupakan bagian dari peer counseling. Para siswa calon peer counselor akan mendapatkan serangkaian pelatihan yang memadai untuk menjadi konselor sebaya sehingga diharapkan mampu meningkatkan kemampuan siswa (yang dilatih sebagai peer conselor dan konseli yang dibimbingnya) dalam menghadapi masalah.

\section{SIMPULAN}

Sehubungan dengan situasi pandemi Covid19 mau tidak mau semua elemen masyarakat, tatanan pendidikan menyesuaikan dengan protocol kesehatan. Kesehatan peserta didik lebih utama sehingga pembelajaran dalam jaringan (daring) salah satu metode yang diterapkan dan membawa dampak besar bagi peserta didik dan guru, tidak menutup kemungkinnan dalam pemberian layanan bimbingan konseling, oleh sebab itu guru bimbingan konseling/konselor harus berani berinovasi dalam pemberian layanan bimbingan konseling ke peserta didik.

Bimbingan dan Konseling merupakan bagian dari program sekolah dalam hal proses pemberian bantuan kepada individu (peserta didik) lebih utama peserta didik tidak melaksanakan pembelajaran tatap muka dapat dilaksanakan melalui berbagai macam layanan. Pembelajaran daring bisa menggunakan media aplikasi whatsapp, google classroom, zoom, google meet, dsb. Bertujuan menjadikan proses bimbingan dan konseling lebih menarik, interaktif, serta inovatif yang tidak terhambat oleh ruang dan waktu. Namun tetap memerhatikan azas-azas dan kode etik dalam bimbingan dan konseling. Berikut ini beberapa inovasi dalam memberikan layanan Bimbingan Konseling pada peserta didik di masa pandemi Covid-19, yaitu.

1. Pembelajaran bimbingan konseling via Zoom, Google Meet, webex meet, Google Clasroom.

2. Pemberian layanan konseling melalui, Whatsaap, facebook dsb.

3. Pemberian sinema konseling Via Youtube untuk metode motivasi dalam masa pandemi covid-19

4. Mengoptimalkan peer counseling melalui media daring dalam masa pandemic covid-19.

Tidak ada alasan apapun dalam masa pandemi covid-19 guru bimbingan konseling/konselor berhenti memberikan layanan kepada peserta didik, bahkan dengan adanya pandemi seperti ini semua guru bimbingan konseling dikenalkan dengan beberapa macam metode aplikasi pembelajaran daring sehingga menambah keterampilan diri dalam menggunakan layanan bimbingan konseling berbasing daring.

\section{Daftar Pustaka}

Astiti, Shofi Puji, (2019). Efektifitas konseling sebaya dalam menuntaskan masalah siswa. Tersedia e-journal.iainsalatiga.ac.id /index.php/ijip/index. di akses tanggal 06 Oktober 2020

Dindah, (2017) Inovsi baru dalam layanan bimbingan konseling,Tersedia:https: //blog.uad.ac.id/dindah1600001085/2017/07 /25 di akses tanggal 06 Oktober 2020

Eliasa, E. I., \& Iswanti, S. (2014). Bibliotherapy with the Career Topic to Increase the Student's Career Motivation of Guidance and Counseling. Procedia-Social and Behavioral Sciences, 114, 434-438. di akses tanggal 06 Oktober 2020

Erhamwilda, (2011). Peningkatan Kompetensi Intrapersonal Siswa SMK melalui Model Konseling Sebaya, Bandung: Universitas Islam Bandung.

Hunainah. (2011). Teori dan Implementasi Model Konseling Sebaya, Bandung: Rizki Pres.

Hunainah. (2012). Bimbingan Teknis Implementasi Model Konseling Sebaya, Bandung: Rizki Press. 
Mulawarman, Hariyadi, sigit. (2019). SinemaKonseling untuk Meningkat kan Ketahanan Psikologis Siswa Sekolah Menengah Kejuruan pada Era Digital. Tersedia ejournal.ilininstitute.com/index.php/ caradde Volume 2 di akses tanggal 06 Oktober 2020

Perdana, Mas, Adi, Putra, Shofaria Nurida. (2019). Ragam Profesionalisme Guru Bimbingan dan Konseling Zaman Now. Tersedia: https://journal.unesa.ac.id/index.php/jbk/arti cle/view/3776. di akses tanggal 06 Oktober 2020

Perdana, M.A.P.A (2018) Modul Layanan Bimbingan dan Konseling SMK Kelas X. Lamongan: Lotuz Grafika

Perdana, M.A.P.A (2018) Modul Layanan Bimbingan dan Konseling SMK Kelas XI. Lamongan: Lotuz Grafika

Perdana, M.A.P.A (2018) Modul Layanan Bimbingan dan Konseling SMK Kelas XII. Lamongan: Lotuz Grafika

Sholihah, I. N. M. (2018, October). Kajian teoritis penggunaan art therapy dalam pelaksanaan layanan bimbingan dan konseling di SMK. In 1st ASEAN School Counselor Conference on Innovation and Creativity in Counseling. Ikatan Bimbingan dan Konseling Sekolah.

Slavin, R.E. (2006). Education Psychology . Boston. Allyn and Bacon.

Sudarman, Danin. 2002. Inovasi Pendidikan Dalam Upaya Peningkatan Profesionalisme Tenaga Kependidikan, Pustaka Setia: Bandung

Suherman, Uman. 2009. Manajemen Bimbingan dan Konseling. Bandung : Rizqi Press

Suraneta, K. (2013). Pengembangan Model Tutor Bimbingan Konseling Sebaya (peer counseling) untuk Mengatasi Masalah Mahasiswa Universitas Pendidikan UNDIKSHA. Bali: Universitas Pendidikan Ganesa. 